\title{
Kahramanmaras Germenicia Mozaiklerinin Konu Ve Uygulama Teknikleri Bakımından Değerlendirilmesi
}

Mehmet Akif KAPLAN*

Kaplan, M. (2019). Kahramanmaraş Germenicia mozaiklerinin konu ve uygulama teknikleri bakımından değerlendirilmesi. YEDİ: Sanat, Tasarım ve Bilim Dergisi, Yaz 2019 (22), s. 141-150

Derleme Makale / Review Article

Özet

Mozaik sanatı kesilmiş küçük boyutlu renkli parçaların duvar ya da zemin yüzeyine belli bir ritim ve sıraya göre, araların çok az boşluk kalacak şekilde, yerleştirilmesiyle oluşan bir tasvir, resim veya dekorasyondur.Mozaik sanatının ilk örnekleri M.0̈. 4000 civarında Mezopotamya'da ortaya çıkmıştır. Batı dünyasının Doğu medeniyetleri ile ilişkileri sonucunda mozaik sanatı Eski Yunan'a ve buradan da Roma’ya geçmiştir. Mozaik sanatının primitif örnekleri sivri koni, geometrik biçimli renkli parçalardan oluşmuştur. Daha sonra gelişen mozaik teknikleriyle küęük renkli taş, cam, seramik gibi parçaların kullanılması mozaik sanatına klasik şeklini vermiştir. Kahramanmaraş Germenicia Mozaikleri de Roma döneminden kalma mozaiklerdir. Germenicia mozaiklerinde konu olarak genellikle yerel ve gündelik yaşam ele alınmıştır.

Anahtar Sözcükler: Mozaik, Mozaik Sanatı, Germenicia, Germenicia Güzeli, Kahramnmaraş.

\section{Evaluation Of Then Kahramanmaraş Germenıcıa Mosaıcs From TheTerms Subject And Applıcatıon Tecniques Abstract}

Abstract

The mosaic art is a depiction, painting or decoration formed by placing small sized colored pieces on the wall or floor surface in a certain rhythm and order, with little space between them. The first examples of mosaic art 4000 appeared in Mesopotamia. As a result of therelations of the Western world with the Eastern civilizations, the art of mosaics went to Ancient Greece and from here to Rome. The primitive samples of mosaic art consist of pointed cone and geometric colored pieces. Theuse of small colored stones, glass and ceramics as a result of the mosaic techniques developed later gave the mosaic its classical form. The art of mosaic sappears only in ancient Rome. Kahramanmaraş Germenicia Mosaics are mosaics dating from the Roman period. In Germenicia mosaics, local and daily life is generally discussed.

Keywords: Mosaic, Mosaic Art, Germanicia,Beautiful of Germenicia, Kahramanmaraş. 


\section{Giriş}

Bu araştırmada Roma Döneminde yapılan Germenicia Mozaikleri konu ve kompozisyon özellikleri açısından değerlendirilmiştir. Değerlendirmenin sağlıklı yapılması için mozaik sanatı, mozaik sanatının tarihçesi ve teknik açıdan gelişim seyri de ele alınmıştır. Germenicia mozaiklerinin diğer Roma mozaikleriyle konu açısından benzerlik ve farklılıklarına değinilmiştir. Yöntem olarak betimsel tarama ve yerinde inceleme yöntemi kullanılmıştır.

Mozaik sanatı insanlığın ortaya koyduğu en eski resimleme, betimleme, tasvir etme tekniklerinden biridir. Sanat insanlık tarihiyle başlamış ve sürekli olarak kullanılan malzeme, teknik ve sunuş biçimleri gelişme göstermiştir. Her çağ kendi sanat yöntemini, araç gereç ve malzemelerini kendi tarihsel gerçekliği içerisinde ortaya koymuştur. Mağara resimleriyle başlayan serüven farklı teknik ve yöntemlere bağlı uygulama biçimleriyle günümüze kadar gelmiştir. Mozaik sanatı da kendine özgü teknik, malzeme ve uygulama biçimiyle bir gelişim seyri içerisinde var olmuştur.Mezopotamya'da başlamış ve Eski Yunan, Roma, Bizans gibi dünyanın diğer medeniyetlerine yayılmıştır. Antik Yunan dünyası mozaik sanatı tekniğini daha da geliştirmiştir. Antik Yunan kültür mirası üzerine konmuş olan Roma ise mozaiğikendi kültürüyle kaynaştırarakhemen hemen son şeklini vermiştir.

Roma İmparatorluğu kendi egemenliği altına aldığı coğrafyalarda yaşayan medeniyetlere kendi kültürünü nakletmiştir. Anadolu'da yer alan toplulukların çoğunu da kendi egemenliği altına alan Roma, bu topraklara mozaik sanatını getirmiştir. Roma İmparatorluğu Anadolu'daki şehirlerden Antakya, Zeugma (G. Antep), Halepli Bahçe (Ş. Urfa), Kommagene (Adıyaman), Efes (İzmir) gibi yerlerde M.Ö. 300 ile M.S. 400 tarihleri arasında yapılan mozaiklerin büyük bir çoğunluğunu mitolojik konular oluşturmaktadır. Ancak, nadir olarak yerel yaşantının, yerel kültürün ve coğrafyanın özelliklerinin yansıtıldığı konular da işlenmiştir. Bu güne kadar ortaya çıkarılan Germenicia mozaiklerinin de konusu daha çok yerel yaşantının ele alındığı sahnelerdir.

Roma İmparatorluğunun (M.Ö. 600- M.S. 400) en parlak döneminde Anadolu'nun Güneydoğu bölgesinde, imparatorluğa bağlı olarak hüküm süren Kommagene Krallığı'nın (M.0̈. 100-M.S. 400) önemli dört kenti bulunmaktadır. AntepZeugma, Adıyaman-Samosata ve Malatya-Melitene'dir. Bunlardan biri de Kahramanmaraş- Germenicia'dır. Aynı zamanda
Adiyaman-Edessa ve Hatay-Antiokya bölgenin önemli Roma şehirlerindendir. Bu bölgedeki birbirine yakın olan Roma şehirleri ticari, siyasi ve kültürel alışveriş içinde olmuşlardır. Dolayısıyla bu bölge şehirlerinde çıkarılan mozaikler yapılış kalıpları bakımından benzerlikler göstermektedir (Koç, 2009: 1-8). ${ }^{1}$

\section{Mozaik Sanatı}

Mozaik sanatı küçük kesilmiş taş parçalarının hazırlanan harç tabakası üzerine dizilerek bir betimleme, tasvir ya da motif oluşturulmasıdır. "Mozaik küçük boyutlu renkli parçacıkların bir düzlem üzerinde birbirine bitişik olarak yerleştirmeleriyle oluşturulan bezeli yüzey” (Sözen ve Tanyeli, 1996: 166). Fisher'e göre "mozaik her bir tamamlayıcı, bileşen elemanın düzen oluşturduğu bir resim veya duvar dekorasyonudur”(Fisher, 1971: 7). Mozaik mimari yapıların duvar ve zeminlerinin renkli taş, cam gibi parçalarla çeşitli tasvirlerin ya da süslemelerin yapılması işidir.

Mozaiksanatı kapladığıyüzeye göre sınıflandırılmıştır. Bu bakımdan mozaik sanatını duvar ve zemin mozaiği olarak ayırmak gerekmektedir. Zemin mozaiği mimari yapıların zeminine, duvar mozaiği de mimari yapıların duvarlarına yapılmıştır. Zemin ve duvar olarak sınıflandırılan mozaiklerin taşların yüzeyi ve derinliği hususunda farklılıkları vardır. Bu konuyla alakalı olarak,Fisher bir zemin mozaiğinin hem malzemesinin hem de montajının sağlam ve pürüzsüz olması gerektiğini belirtir. Diğer taraftan üzerinde gezilmeyen duvar ve tavan mozaiği daha az sağlam malzemeden yapılabilir ve pürüzsüz bir yüzeye sahip olmak zorunda değildir; mozaiği oluşturan parçalar farklı açılarda ve düzlemlerde olabilir (Fisher, 1971: 34).

Mozaik kelimesi etimolojisininhangi kelimeden türediği kesin olmamakla birlikte, Grekçe'de yer alan “mousa” kelimesinden türemiş olabileceği söylenir.Mousa kelimesi Roma Dönemi'nde “musivum”, Ortaçağ’da “musaicus” olarak değişmiştir. Latincede “musivum opus”olarak isimlendirilen mozaik eserler, ortaçağa kadar çeşitli şekillerde yazılmışlardır. Mozaik kelimesi ilk olarak Diocletien zamanındaki Latince bir eserde yer almış, daha sonra musivum olarak değişime uğramıştır.

Mozaik taşlara tesserula ya da tessera, mozaik döşemelere

1Ali Koç tarafından hazırlanan Germenicia Mozaikleri Hakkında Bilirkişi Raporu. Ali Koç izniyle alıntılar yapılmıştır. 
ise povimentatesselata denmektedir. Musivum, taşçıklarından duvar resmi anlamına gelmektedir. Bu kelime,mozaikin genel anlamda tanımıdır. Yani bir mimari yapıyı süsleme sanatı olarak mozaik, çeşitli renkte küçük taş parçaları veya pişmiş topraktan yapılmış parçalarla ya da cam parçalarıyla, bir harç yatağına yan yana dizilerek ve aynı seviyede düzleştirilerek yapıştırılır. Mozaik yapan sanatçıyı isemusivarius, museiarius, museariusismi karşılamaktadır (Üstüner, 2002: 7).

\section{Mozaik Sanatının Tarihi}

Mozaik sanatının tarihsel gelişiminde ilk örnekleri M.Ö. 4000 Mezopotamya'da Sümer ve Mısır sanatında ortaya çıkmıştır. Batı'nınDoğu'yla ticari ilişkileri sonucu mozaik sanatının etkileri Eski Yunan'a ve buradan Roma İmparatorluğuna geçmiştir. Mezopotamya'da M.Ö. 2600 yılında Uruk kazılarında ortaya çıkartılan mozaiklerin bir kısmı renkli sivri konilerin duvara çakılmasıyla yapılmış; bir kısmı ise geometrik biçimlerde kesilmiş küçük renkli öğelerin bir yüzeye yapıştırılması tekniğiyle gerçekleştirilmiştir. Küp biçimli parçaların sıva üzerine yapıştırılması tekniği, yani gerçek mozaik, ancak Antik Roma'da ortaya çıkmış, bunlar duvar ve zemin mozaiği olarak kullanılmıştır (Sözen ve Tanyeli, 1996: 166).

Mezopotamya'da ilk örnekleri ortaya çıkan mozaik süslemeler sonraki dönemlerde mimari yapılarda yeni uygulamalarla gelişim göstermiştir. Pişmiş topraktan yapılan ve huni biçimli parçaların görece sivri kısmının uygulama yapılacak alana, yassılaştırılmış kısmın ise dekorasyonu tamamlamak amacıyla üstte kalacak şekilde yerleştirilmesi ile oluşturulur. Bu mozaik tekniği duvar mozaiklerinin öncüsü niteliğindedir. Kullanılan motifler çanak çömlekler ve mühürler üzerinde de uygulanan geometrik motiflerden oluşmuştur (Ekincioğlu, Başıbüyük, Gölbaş ve KayduAkbudak, 2018: 84).

Gür, mozaik sanatının Helenistik dönemde başladığı$\mathrm{n}$ ve Roma döneminde devam ettiğini söyler. Gerçek manada mozaik sanatının ilk örnekleri yuvarlak taşlardan yapılmıştır. Daha sonra ise küp şeklinde kesilmiş taşlarla yapılır. Bizans'ın arkaik döneminde ise mozaik sanatı camdan yapılmış ve üzeri altın, gümüş ve boya ile kaplanmıştır. Bizans mozaik ustaları bir ressam gibi çalışmış, figürlerde ışık-gölge oyunları başarı ile uygulanmıştır. Mozaik taşları küçüldükçe tasvir edilen figür veya motif daha mükemmel bir görünüme kavuşmuştur (Gür, 2007: 130).

Üstüner'e göre Roma mozaikleri İmparatorluğun merkezinden doğu ve batı eyaletlerinin hepsine yayılmıştır.
İmparatorluk parçalanmasından sonra mozaik sanatı İran ve Bizans topraklarında gelişimi sürdürmüştür. Ancak, Eski Yunan ve Roma'nın etkileri en fazla Bizans sanatında görülür (Üstüner, 2002: 9). Bizans mozaikleri etkilerini Yunan ve Roma'dan alsa da Hıristiyanlıkla birlikte mitolojinin yerini dini konulara bırakmaya başlar. Hıristiyan Bizans toplumunda işlenen konuların ikonalardan oluşması sebebiyle, mozaikler zeminden duvarlara taşınmaya başlar.

\section{Mozaik Sanatında Teknik Gelişmeler}

Mozaik eski çağlardan günümüze kadar değişik biçimlerde uygulanmıştır. Mozaik uygulamalarda tekniğin gelişimine bağlı olarak kullanılan malzeme ve onu işleme yöntemlerinde değişiklikler ve yenilikler ortaya konmuştur.

Mozaik sanatının primitif örnekleri tamamen geometrik geniş yüzeyli parçalar duvar ve zemine hazırlanan bir harç içine gömülerek oluşturulmuştur. Genç, mozaik tekniğinin bu ilk örneklerini Sümerlerin kendi ev ve tapınaklarının dış cephelerini konik biçimdeki renkli parçaları yüzeye sıvanan harca gömerek yaptıklarını belirtir. Mısırlılar mozaik tekniğine cam parçalarını ekleyerek yeni bir malzeme ve teknik getirmişlerdir.Antik Yunanlılar ise mozaik sanatının gelişmesine altın plaka ve değerli süs taşlarını dâhil etmişlerdir.Mekadonya'da (Olynthos) M.Ö. 5. Yüzyıl'dan kalma, tapınakların zemin kaplamalarında, doğal renkli taşlardan oluşturulmuş dekoratif düzenlemeler bulunmuştur (Genç, 1994: 87-93).

Antik Yunan'da mozaikler nehir ve deniz kenarından toplanan çakıl taşları, harç içine döşenerek yapılmıştır. Bunun örneği M.Ö. 6. yüzyıl'dan kalma Delfi'deki Athena Pronaia Tapınağı'nın zemin mozaiğinde görülmektedir. İlk aşamalarda genellikle siyah ve beyaz renkli çakıl taşlarını içeren geometrik tasarımlar ve bitki süslemelerinden oluşur(Fisher, 1971: 35 36).

İtalya'da mozaik yapımında suya dayanıklı bir harc (coccopesto) keşfedilmiştir. Suya dayanıklı harcın bulunması mozaik tekniği açısından oldukça önemlidir. Bu harç, İtalya'da çok rastlanan bir tür volkanik kum olan pozzolano'ya kireç kaymağı, sertleştirici dolgu malzemesi olarak da mermer ve seramik kırıkları katılarak oluşturulan bir karışımdır. Sonraki uygulamalarda harcın içineseramik kırıkları yerine küp biçiminde kesilmiş “tessera”lareklenmiştir (Genç, 1994: 87-93).

Mozaik yapımında kullanılan taş malzemenin cinsleri, roma döneminde de aynıları kullanılmasına rağmen, M.Ö. II. 
Yüzyıl'dan sonra, cam hamurundan yapılan küpler boyanarak fırına verilmesiyle renkler sabitlenmiştir. Bu fırında pişirilerek renklendirilen parçalar kompozisyonlardaki renk çokluğu ve farklılığı, nüansların oluşturulmasında kullanılmıştır (Üstüner, 2002: 85).

Roma dönemi mozaikleri kullanılan parçalarınboyutlarına, malzemesine ve geometrik düzenine göre opus tesselatum, opus vermiculatum, opus signium, opus sectile ve opus musivum olarak beş kategoriye ayrılır.

Opus Tesselatum: Roma'da M. Ö. 2. Yüzyıldan itibaren düzgün kesilmiş renkli taşlar, mermer ve seramik tesseralar kullanılarak duvara ve zemine uygulanan mozaik yapma tekniğidir. Opus Tesselatum tekniğisu geçirmez özelliğe sahip olduğu için genellikle Roma hamamlarında kullanılmıştır.Aynı zamanda bu tekniğin yapıldığı yüzyıllar Anadolu’nun Güneydoğusunda bulunan Kommagene Krallığı'nda ortaya çıkarılan mozaiklerin yapıldığı dönemlerdir. Bu bakımdan Zeugma, Edessa, Antiokya ve Germenicia mozaiklerinin Opus Tesselatum tekniğiyle yapıldığı söylenebilir.

Opus Vermiculatum:Vermiculatum tekniği Mısır uygarlığına dayanır. Bu mozaik tekniğinde renkli küçük taş tesseralar kullanılır. Canlı yüzeylerde kırmızı, sarı ve turkuaz renkli camlar kullanılmıştır. Opus Vermiculatum tekniği daha çok, banyolar, havuzlar ve çeşmeler gibi sulu mekanlarda kullanılmıştır(Genç, 1994: 87-93).

Opus Signium:Mozaik yapılacak olan yüzeye kırmızı tuğla kırıklarıyla hazırlanmış harcın içerisine mermer ve seramik parçaları harca rastgele dökülüp karıştırılarak yapılırdı. Opus SigniumtekniğiM.Ö. 2. Yüzyıl ve M.S. 2. Yüzyıla kadar devam etmiştir. Bu teknik İtalya'da genellikle mimari yapıların avlularında ve çeşitli odalarında kullanılmıştır

Opus Sectile:Opus Sectile mozaik tekniği çeşitli renkte tesseralar ve mermer parçaları ile yapılmıştır. Mozaikte kullanılan mermer parçalar üçgen, kare veya dikdörtgen şeklindedir. Bu mozaikler genellikle avlulara, banyolara ve yemek odalarına uygulanmıştır (Kaplan, İpekoğlu ve Böke, 2017: 3).

Opus Musivum:Vermiculatum tekniğine benzeyen bu teknikte cam tesseralarkullanılmıştır. Genel olarak yapıların duvarlarında kullanılmıştır. Opus Musivumfresko tekniğinde resim çizgi ve renkleriyle duvara yapılırdı ve üzerine mozaik parçalar dizilmekteydi(Genç, 1994: 87-93).

Mozaik Harç Katmanları, hazırlık harç katmanları ve
Tesselatum katmanı olmak üzere ikiye ayrılır. Hazırlık harç katmanları zeminden yüzeye doğru statumen (Dranej), Rudus (Kaba Harç), Nucleus (İnce Harç) ve bedding (Yatak Harcı) olmak üzere dörde ayrılır.

1. Dranej Katmanı (Statumen):İlk hazırlık katmanıdır. Zemin üzerine iri taşlar kullanıp hazırlanarak mozaik uygulanacak yüzeyin düzeltmesi işlemidir.

2. Kaba Harc Katmanı (Rudus):Rudus katmanı Dranejkatmanı üzerinde bulunan ikinci hazırlık harç katmanıdır. Kum, taş, tuğla ve kireçten oluşan rudus katmanı zeminden gelen nemin mozaik yüzeye ulaşmasını önlemek için uygulanmaktadır.

3. İnce Harç Katmanı (Nucleus): İnce harç katmanı rudus üzerinde yer alır ve üçüncü hazırlık katmanıdır. Kum, taş, tuğla parçaları ve kireç kullanılarak hazırlanır. Nucleusrudus katmanından daha ince bir harç katmanıdır (Kaplan vd. 2017: 3-5).

4. Yatak Harcı (Bedding): Hazırlık katmanıdır. Dunbain'e göre kireç bakımından oldukça zengin bir harç katmanı olan Yatak harcı katmanı, İnce Harç katmanı üzerine ince bir şekilde serilir ve üzerine mozaik taşları yerleştirilir (Dunbain'den aktaran Kaplan vd. 2017: 3-5)

\begin{tabular}{|c|}
\hline Derz harcı (Tesselatum katmanı.). \\
\hline Yatak Harcı (Bedding) \\
\hline İnce Harç Katmanı (Nucleus) \\
\hline Kaba Harc Katmanı (Rudus) \\
\hline Dranej Katmanı (Statumen) \\
\hline
\end{tabular}

Tablo 1:Mozaik Yapımında Kullanılan Harç Katmanları.

Tesselatum Katmanı ise tesserea ve tesseraların (mozaik taşlarının) arasını dolduran derz harcından oluşmaktadır ve mozaiğin en üst kısmını oluşturur. Tesseralar mozaik desenine göre hazırlanan taş, mermer, pişmiş toprak, cam ve seramiklerdir. Tesseralar yapılacak mozaiğin desenine göre yatak harcına çeşitli şekillerde yerleştirilir.

Bir mozaik yapımı önce yapılacak olan mozaik tasarımının çizilmesiyle başlar. Daha sonra ise uygulanacak mozaiğin teknik ve desenine bağlı kalarak taşların döşenmesi için hazırlanmış mozaik harç katmanının üzerine yarı yerine kadar gömül 
mesi aşamalarından oluşur. Bu Roma ve daha sonra Bizans’ta uygulanan klasik mozaik tekniğidir. Geliştirilen Modern tekniklerde ise, özellikle eğitim amaçlı uygulanan yöntemler, taşınabilir, mozaiğin yapılacağı alana daha sonra montaj işleminin yapılması şeklinde uygulamalar içermektedir.Modern tekniklerde de klasik yöntemde olduğu gibi yapılacak olan mozaik bir tasarımla başlar. Sonraki süreçte mozaik uygulamasının boyutlarının belirlenmesi, buna göre ahşap kalıp hazırlanması ve bu kalıbın içerisine bir santimetre yüksekliğinde merdane yardımıyla kil döşenmesidir. Böylelikle ilk aşama tamamlanır. Bu kil tabakanın üzerine tasarlanan mozaik deseni sivri bir uçla çizilir. Daha sonra bu kil üzerine bir santimetre küp olan renkli mozaik taş parçalarının yarısına kadar batırılmasıyla taş dizme işlemi gerçekleşir. Mozaik taşlarının dizilmesinden sonra oldukça sıvı ve ince bir harç hazırlanır ve kil içerisine döşenen taşların üzerine boşluk bırakmadan yayılması sağlanır. Bu harç katmanı kuruduktan sonra daha kalın ve içerisinde mermer parçacıkları bulunan bir harç yapılarak ince harç katmanının üzerine dökülerek güzelce düzleştirilir. Bu harç katmanı da kuruduktan sonra çalışma ters çevrilir. Kil tabaka su ve fırça yardımıyla temizlenerek kil içerisinde gömülü taşlar yani orijinal mozaik ortaya çıkarılmasıyla çalışmanın yapımı gerçekleşmiş olur.En nihayetinde ise çalışılan mozaik monte edileceği alana götürülerek montajı yapılır. Bir diğer modern mozaik uygulamada farkı bir teknik kullanılır. Çalışılacak olan mozaik deseni ya da tasarımı bir kâğıt üzerine çizilerek renklendirilir. Bu mozaik deseni düz bir zemine serilir, serilen desen üzerine aynı boyutta asetat ve asetatın üzerine de file çekilir. Mozaik tasarımına bağlı kalarak taşlar tutkal ile sabitlenmek üzere dizilir. Çalışma tamamlandıktan sonra file üzerine yapıştırılan mozaik taşları fileyle birlikte asetattan ayrıştırılır. Daha sonra file ile birlikte mozaik çalışması uygulanması gereken alana yine harç katmanlarıla monte edilir.

\section{Kahramanmaraş Germenicia Mozaikleri ve Çalışılan Konular}

Kahramanmaraş Hititler, Asurlular, Makedonyalılar, Selefkoslar ve Romalılar gibi birçok devletin kurulduğu bir bölge olarak tarihteki yerini almıştır. Kahramanmaraş’ta kurulan her devlet kendi kültürünü de buraya nakletmiştir. Dolayısıyla Kahramanmaraş kültürel çeşitlilik bakımından oldukça zengin bir geçmişe sahiptir. Araştırmada bu başlık altında Maraş tarihi hakkında kısa bilgi vermek ve Maraş’ta hâkimiyet süren Büyük Roma İmparatorluğunun bıraktığı kültürel mirası olan mozaikleri konu ve kompozisyonu bakımından ele almak hedeflenmektedir.
Maraş’ın Hititler dönemindeki adının 'Markasi’ olduğu bilinmektedir. M.Ö. 58'de Büyük Roma İmparatorluğu şehri ele geçirmiştir. Roma döneminde Maraş, Kommegene Krallığına bağlanmıştır. Romalılar zamanında şehir Anadolu ile Suriye arasındaki geçitler üzerinde bulunmasından ötürü stratejik bakımdan önemli bir yerdir.IV. Antokos burada var olan şehre Germenicia adını vermiştir. Germenicia adı şehre Gaius ve Claudis'u şereflendirmek üzere verilmiştir (Gökhan,2014: 7679). Diğer bir kaynağa göre ise Roma döneminde kent Romalıların egemenliği altına girmiştir. Roma komutanı GaiusCaesar, Germenicus (Caligula) onuruna şehre Germenicia adını vermiştir (Ersoy, 2010: 185).

Germenicia mozaikleri Kahramanmaraş merkez Dulkadiroğlu mahallesinde ve Çağlayancerit ilçesi Küçük Cerit köyünde yapılan inşaatın kazısında tespit edilmiştir. Dulkadiroğlu'nda bulunan mozaikler Germenicia mozaikleri olarak adlandırılır (Küçük ve Yar, 2012: 89) .

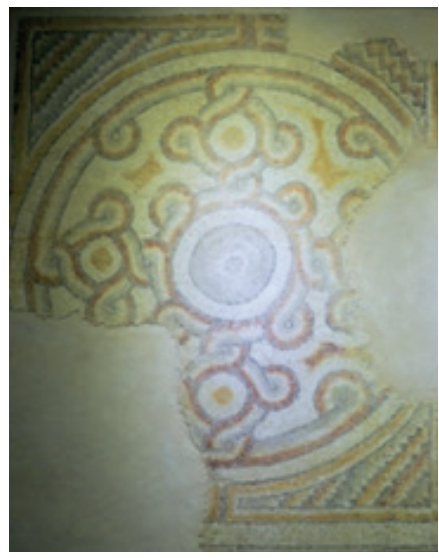

Resim 1: Çağlayancerit’te Bulunan Roma Dönemi Rozet Mozaiği.

Çağlayancerit ve Germenicia mozaiklerinin iki ayrı türde olduğu görülür. Bunlar Roset mozaikler ve gündelik yaşamın öğelerine yer verilen zemin mozaikleridir. Bu mozaik türü M.Ö. 2. Yy. ve 1. Yy.'da Roma'da yaygın olarak duvarlara ve zemine uygulanan Opus Tessalatum denilen mozaik yapma tekniğidir. Bu teknikte düzgün kesilmiş renkli taşlar, mermer ve renkli tesseralar kullanılmıştır.

Maraş mozaiklerinde en çok kullanılan imgeler, avcı figürünün yanı sıra, keklik, horoz, ördek gibi çeşitli kuş türleri ve tilki, ayı gibi vahşi av hayvanları vb.dir.Mozaiklerde tasvir edilen hayvanlar av konusu içerisinde renkli mermer taşlar ve tesseralar ile tasvir edilmiştir. Germenicia mozaiklerinde yer alan tüm figürler beyaz zemin üzerine yapılmıştır. 


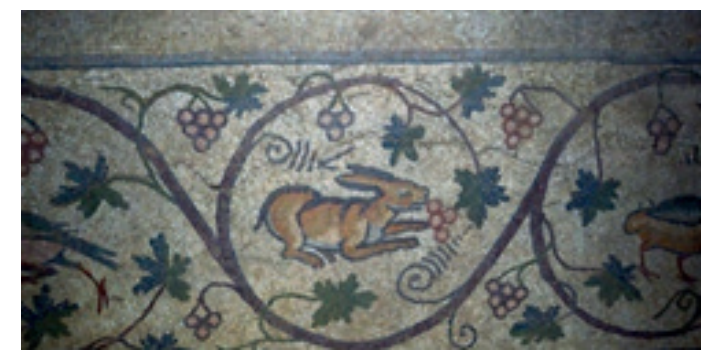

Resim 2: Asma dalları arasında üzümyemekte olan hayvan figürleri.

Ortaya çıkarılan Germenicia mozaiklerinin konularında yer alan figürleri Kahramanmaraş florasının oluşturduğu görülmektedir. Mozaiklerde Germenicia’nın gündelik yaşamı tasvir edilmiştir.Germenicia mozaiklerinin üzerinde genellikle gündelik hayata ait konuların yer aldığını ifade eden Şahin "Baktığımız zaman villalar var, villalarda yaşanan hayatlar var. Bu bize sahiplerinin kim olduklarını ve sosyal statülerini gösteriyor.” (Şahin, 2011) demektedir. Bu gündelik yaşam içerisinde av sahneleri, çeşitli hayvanların otlamaları ve asma bağından üzüm yemeleri yer almaktadır. Zeugma, Antakya, Halepli Bahçe gibi yakın çevre kentlerindeki mozaiklerinin büyük bir çoğunluğunun konusunu Antik Yunan ve Roma mitolojisi oluşturmuştur. Germenicia mozaiklerinin konusunu ise yerel yaşantının oluşturması dikkatleri çekmektedir. Yakın bölgelerden farklı konular ele alınmasında birkaç farklı görüş ortaya konulabilir. Eraslan'a göre bunun nedeni Antioch, Zeugma ve Haleplibahçe mozaiklerinden sonra Helen Stili'ninbozulmasından kaynaklanmaktadır ve bu etkiler M.S. 5. Yüzyıl mozaiklerinde yaygınlaşmaktadır (2013: 230).

Üstüner (2002: 85), Helenizm'den önce kompozisyonlarda daha çok mitolojik öykülere yer verildiğini, günlük konuların ya da ölü doğa betimlemelerinin Hellenizm'de başladığını söyler. Kompozisyonlarda kahramanların, soyluların, yöneticilerin yaşantıları, savaş ve av gibi olaylar yansıtılmıştır. Üstüner'in açıklamasına bağlı kalarakGermenicia mozaiklerinin deHellenizm ve sonrasında yapıldıkları söylemek mümkündür.Germenicia mozaik ustaları gözünü doğaya çevirmiştir. Diğer taraftan Germenicia mozaiklerinin konu kaynağının ve yapılış biçimlerinin daha çok benzerliği Kuzey Afrika ülkelerinde görülmektedir. Buradan anlaşılacağı üzere bir yandan bölgenin hâkim estetik anlayışına bağlı bir üretim yapıldığı, bir yandan da mozaik ustalarının branşlara ayrıldığı ve ustaların kalıplarla çalıştığı söylenebilir.

\section{Av Hayvanları Mozaiği}

Germenicia Mozaiği adını Germenicia kentinin adından almaktadır. Germenicia mozaiğinde ana paneli çevreleyen iki bordür bulunmaktadır. Bu bordürlerde ilki kalın bir şerit şeklinde yapılırken diğeri düz ve ters olarak tekrarlayan çiçek motifi mozaik panelin etrafını çevrelemektedir. Mozaiğin merkez panelinde bir Anforadan asma dallarının yukarı sola doğru ve sağa aşağıya doğru ritimli helezonik tekrarlarla devam ettiği görülmektedir. Asma dallarının oluşturduğu bu helezonik kıvrımların iç kısımlarında İnek, Ayı, Ceylan gibi evcil ve vahşi doğa canlılarının betimlemeleri yer alırken, bu helezonik kıvrımlarına dış kısımlarında ise bir birinden farklı kuş türlerinin tasvirleri yer almaktadır. Bu kompozisyonun benzer örneklerini Gazze'de bulunan Hazor-Ashdod Kilisesi Zemin Mozaiklerinde ve İsrail'de El-MaqerqeshÇapeli'nde görmemiz mümkündür(bknz.Res. 13ve 14).

\section{Avcı Mozaiği:}

Avcı mozaiği M.S. 4.-5. Yüzyıl Geç Roma Dönemine aittir. Bu mozaik bir villanın büyük bir odasının zemin döşemesi olarak yapılmıştır. Avcı mozaiğinin merkez panosunda üç satır şeklinde tasvirler yapılmıştır. Bu tasvirlerde insan, hayvan, ağaç figürleri bulunmaktadır. Merkez panelin kenarında geometrik şekiller, bunun dışını çevreleyen fazla kalın olmayan bir bordür vardır. Bu bordürün dışında mozaik paneli dört bir taraftan çevreleyen, asma dallarından oluşan helezonik dairesel hareketler içerisinde çeşitli hayvanlara ait betimlemeler yer almaktadır. Mozaik panelin en dış kısmı yine bir bordürle çevrelenmektedir. Hachlili asma dalları arasında hayvan figürlerinin betimlenmesi ve koşan hayvan temsillerinin Roma mozaiklerinde popüler olduğunu söyler (Hachlili, 2009: 157).

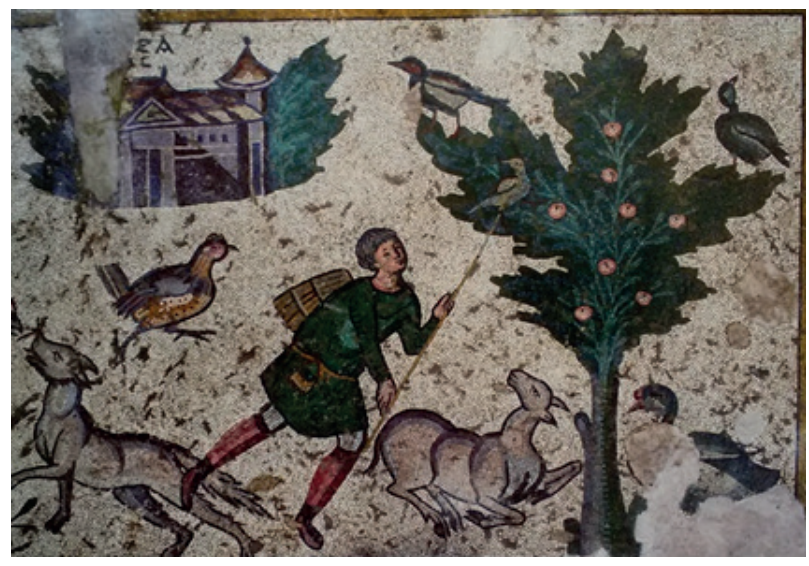

Resim3: Avcı Mozaiği 
Bu panoda Germenicia kentinin gündelik yaşamından sahneler betimlenmiştir. Panelin ilk satırında sırtında selesi ve elinde mızrak benzeri bir av aletiyle ağaçtaki kuşları avlarken betimlenmiştir. Bu satırın sol tarafında kucağında iki kuşu bulunan giyimli ve çizmeli belli ki avdan dönen bir avcı tasviri daha yer almaktadır. Bu figürün hemen önünde bir avcı köpeği veonun önünde, iki avcının ortasında yer alan bir ağaç tasvir edilmiştir. Ağacın altında göletten su içen bir geyik ve hemen yanın da ise tilki ve horozun mücadelesi betimlenmiştir. Geyiğin su içtiği göletin sağında ve solunda ikisi aynı biri faklı olan üç çiçek bulunmaktadır. Bu satırın sol tarafının hemen üst kısmında ise bir Roma villasının tasviri yer almaktadır.Panonun ikinci satırında bir erkek figürü vardır. Avcı figürleriyle kıyaslandığında avcı figürlerinden oldukça büyük betimlenmiştir. Sağ omzu açıktadır ve üzerine bir peplos ve bir pelerin giymiştir. Bu figürün sağında ve solunda iki meyve ağacı vardır. Ersoy, bu figürün villanın sahibi olabileceğini belirtmiştir. Bu orta satırın üst kısmında ise yine bir Roma villası bulunmaktadır. Mozaik panelin üçüncü satırında üç ağaç ve iki mimari yapı yer almaktadır. Bu mimari yapıların Romalı soylulara ait villalar oldukları düşünülebilir.

\section{Geyik Avcısı Mozaiği}

Geyik Avcısı Mozaiği’nin (bknz. Resim 8) en dışında olan kırmızı, beyaz ve siyah tessaralarla oluşturulmuş geometrik motifler yer alır. Orta bordürde stilize, sarmal biçimli, üzerinde üzüm salkımlarının olduğu asma yaprağı motifleri ile bunların arasında keklik, serçe,güvercin betimlemeleri vardır. En içte kalan bordürün iç kısmının dört köşesinde 'Bahar'la, 'Bitki’yle ile ilgili kadın portreleri vardır. Bunlardan en önemlisi 'Bahar Kraliçesi' ya da 'Germenicia Güzeli'dir. Mozaik panelinde stilize bitkisel motifler arasında, genç kadın portresi bordürün tam köşesinde diyagonal bir şekilde durmaktadır.

Bu avcı mozaiğinin merkez panelinde bir elinde mızrağı diğer elinde asası bulunan çizmeli bir avcının geyik avladığı görülmektedir. Avcı yakaladığı geyikleri çit içerisine topladığı görülmektedir. Av sahnesinin etrafı yine bitkisel motiflerle çevrelenmiştir. Ayrıca bu mozaikte bir ressamın elindeki fırçasıyla büyük bir pithos’u resmettiği görülmektedir.

Orta panelde yer alan uzun, sarı saçlı, yakışıklı, giysili, botlu genç adam tasvir edilmiştir. Av sahnesinde beyaz, sarı, turuncu, açık kahverengi, kahverengi, açık yeşil, koyu yeşil ve siyah renkli tesseralar kullanılmıştır.

Bu mozaik panoyu ortadaki av sahnesi ile değerlen- dirdiğimizde konusunu Yunan Mitolojisinden aldığını anlarız. Koç' göre kesin olmamakla birlikte bu kompozisyon konusunu Antik Yunan'daki Adonis efsanesinden alınmıştır ve mozaikteki genç kız portresi de güzellik ve aşk tanrıçası Venüs’tür.

Mitolojide Adonis efsanesi toprak ve bereket hikayesidir. Efsaneye göre Adonis çok yakışıklı bir genç olarak aşk ve güzellik tanrıçası Venüs tarafından sahiplenilmeye çalışılır. Adonis yılın dört ayını yer altında Persephone (Yer altı Tanrıçası) ile geçirmektedir. Baharla birlikte yeryüzüne çıkıp Venüs'le yaşamaya başlar.Adonis ve Venüs'ün yeryüzündeki yaşamı baharı sembolize etmektedir. Toprağın her yere bereket getirmesi sebebiyle bu olay Güney Akdeniz çevresindeki halklar için büyük bir şenliktir. Bu bakımdan burada zengin bitkisel motifler, ormanlık alan ve av hayvanlarıyla beraber toprağın bereketini anlatma amacını taşıyan, bir bahar şenliği sahnesi işlenmiştir. Bu mozaiğin ortasındaki av sahnesi Adonis efsanesinde anlatılan bir bölümdür. Av sahnesinin sağ üst tarafında ormanlık alanda genç ve yakışıklı Adonis, alt tarafta ise bir çitin içerisinde Adonis tarafından yakalanan hayvanlar betimlenmiştir. En içte yer alan bordür içinde bitkisel motifler içerisinde anlamlı bakışlarıyla tanrıça Venüs vardır. Bunun karşısında ise Adonis'e av sırasında yardım eden kanatsız Cupido (Eros) karşısından kendine saldıran aslana ok atar durumdadır. (Cupidolar antik mitolojide tanrıçaların çeşitli konularda yardımcıları olarak işlenmişlerdir. Burada da Cupido tanrıça Venüs ün isteği doğrultusunda, ava giden Adonis'e yardım eder şekilde anlatılmıştır (Koç, 2009).

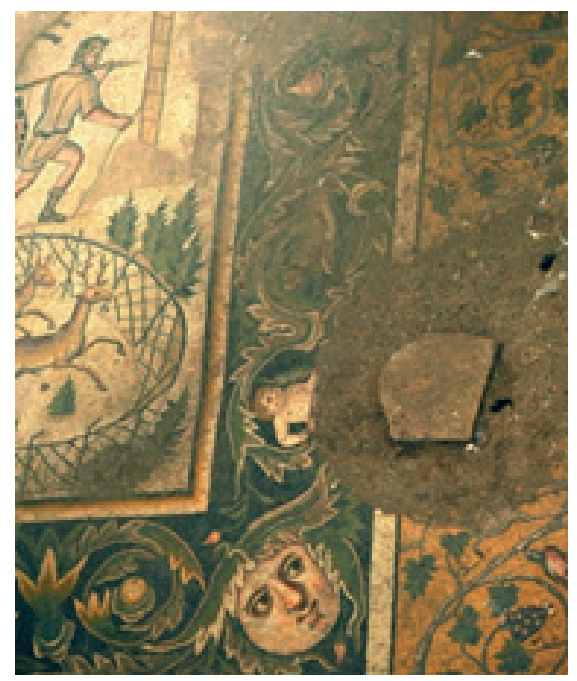

Resim 4: Geyik Avcısı Mozaiği. Eni 3.5 m. Boyu 3. 7 m.M.Ö. 100- M.S. 300. (Koç, 2009). 


\section{Germenicia Mozaiklerinde Horoz ve Tilki Figürü}

Anadolu'da ortaya çıkarılan mozaiklerin en önemli özelliği yaşamsal durumun, hayata ait gündelik sahnelerin yansıtılmasıdır. Özellikle K. Maraş Germenicia mozaikleri Roma döneminin yaşamını anlatmaktadır. Bu mozaikler bazen şaşırtıcı konularıyla da dikkati çekmektedir. Bunların en güzel örneklerinden birisi herkesin dikkatini çeken, Avcı Mozaiği’nde konu olarak sahnelenen horoz ile tilkidir. Şahin (2011) bu kompozisyonda horoz ile tilki muhabbet ettiğini söyleyerek kompozisyonu yorumlamıştır.Kompozisyonu görünce La Fontaine'nin meşhur karga ile tilki hikayesini anımsadığımızı veburada La Fontaine'nin bin 500 yıl öncesine ait belge olduğunu düşünmeyi gerektiriyor. Kompozisyonda karga yerine horoz mu vardı acaba diyerek hikayenin kaynağınınbir ihtimal Kahramanmaraş olabileceğini öne sürmektedir.

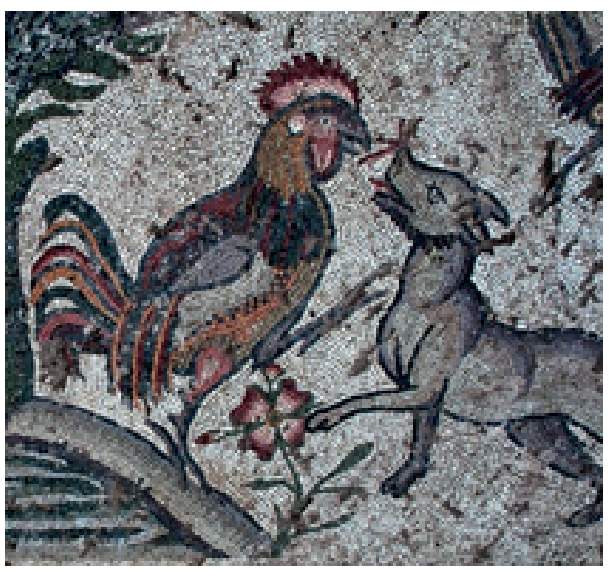

Resim 5: Horoz ile Tilki

\section{Germenicia Mozaiklerinde Venüs, Bahar Kraliçesi ya da Germenicia Güzeli}

Bahar Kraliçesi Geyik Avcısı Mozaiğinin içteki bordürünün tam köşesinde, stilize bitkisel motifler arasında diyagonal bir şekilde durmaktadır. Bahar Kraliçesi'in yönü 4/3 sola dönük haldedir. Portre beyaz, sarı, açık kahverengi, turuncu, kırmızı, bordo ve siyah tesseralarla yapılmıştır. Yüz kısmında oldukça iyi bir şekilde ışık-gölge tekniği uygulanmıştır. Portrenin hemen sağında bitkisel süslemeler içerisinde ok atan çocuk figürünün belden yukarısı görülmektedir.

Koç’a göre bu portre Germenicia güzelidir. Ona göre, Germenicia'da çıkarılan genç kadın portresini, diğerlerinden (G.Antep- Zeugma'Çingene Güzeli', ŞanlıUrfa-Edessa 'Edessa Güzeli') ayırt etmek gerekirse 'Germenicia Güzeli’ olarak isimlendirilebilir; Ya da Adonis ile Venüs arasındaki efsaneye göre ele alırsak bu portre Venüs’tür.

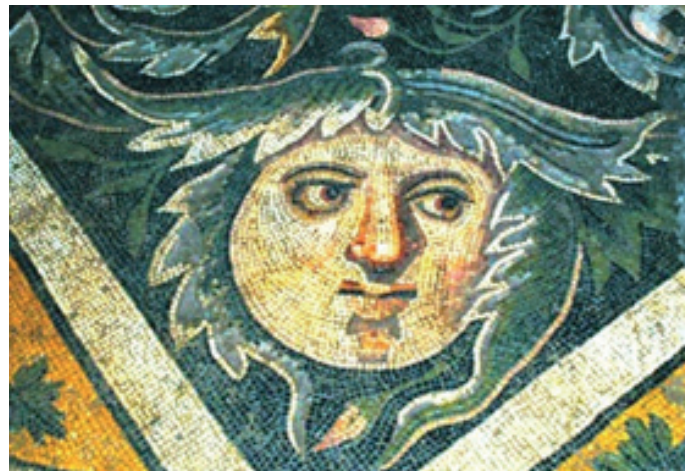

Resim 6:Germenicia Güzeli.

\section{Germenicia Mozaiklerinde Ressam Figürü}

Germenicia mozaiklerinde yer alan en ilginç, hatta daha önce hiç görülmemiş bir ressam figürü bulunmaktadır. Sarı giysisiyle yere çömelerek dizi üzerine uzanmış vaziyette kaide üzerinde duran bir amforayı resimleyen elinde fırçasıyla genç bir ressam betimlenmiştir. Sarı elbisesini siyah bordürlerle çevrelenmiş ressam figürünün ayakları çıplaktır. Bakışını amforadaki ayrıntıya odaklayan ressam titizlikle çalışmasını yapmaktadır.

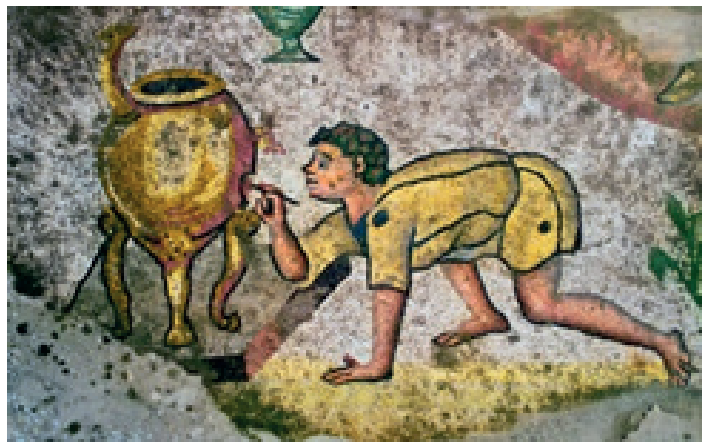

Resim 7:Ressam Figürü.

\section{Germenicia Mozaiklerinde Kompozisyon}

Germenicia kompozisyonları genellikle büyük bir panel ve bunun etrafını çevreleyen birbirinden farklı bordürlerle çevrelenmiş olarak yapılır. Bu bordürler kimi zaman geometrik figürlerle kimi zamanda düz renk şerit olarak yapılmıştır. Bordür dışında mozaiğin ana panelinin etrafını asma dalları ve bu helezonik asma dallarının içerisinde çeşitli hayvan figürlerinin yer aldığı bir düzen de görülür. Asma dalları ve hayvan figürleri çoğu zamanda mozaiğin panelinde yer alan ana temayı oluşturdukları dikkati çeker.

Dulkadiroğlu’ndaki asmalı mozaikler geometrik, da 
iresel hareketlerle bölünen kompozisyonlardır. Mozaik panonun tabanında yer alan bir vazodan çıkan asma dalları gruplara bölünmüştür. Kompozisyon bazen hayvan avlama sahneleriyle birlikte değişen kuş ve hayvan sıralarından oluşmaktadır. Mozaik kompozisyonlarında helozonik kıvrımlarda kullanılan her bir asma dalının ortasında bir hayvan figürü yer almaktadır. Bu kompozisyon tekniği Helenistik ve Roma döneminde ortaya çıkmıştır.

Tüm zemini eşit bir şekilde kaplayan simetrik ve geometrik olarak tasarlanmıştır. Asma dallarının dairesel hareketlerine farklı kuş türleri, hayvanlar ve diğer nesneler katkı sağlamaktadırlar. Mozaik kompozisyonlarını bazen de insan figürleri, av sahneleri ve kırsal gündelik faaliyetler içerisinde görürüz.
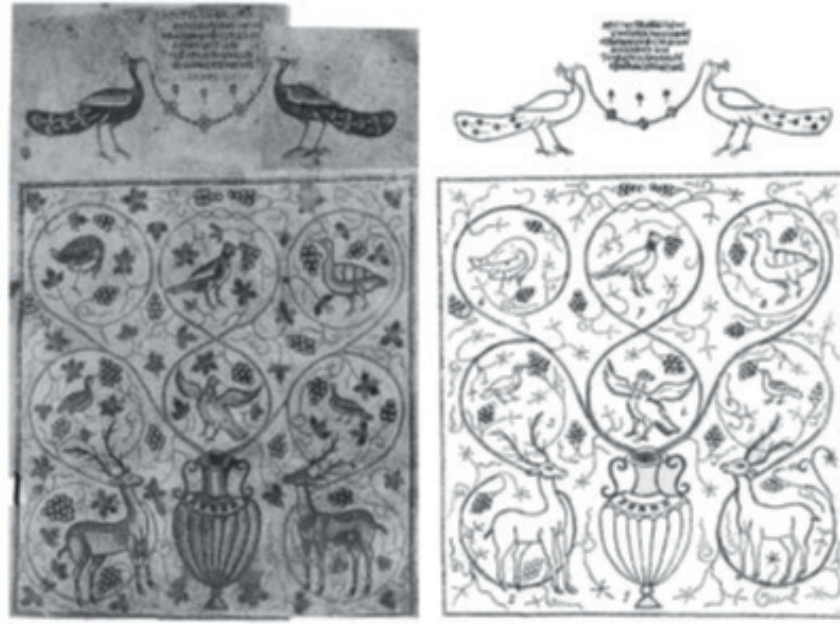

Resim 8:El-Maqerqesh Çapeli, 6. Yy. İsrail. (Hachlili, 127)

Germenicia mozaiklerinin asma dallarından ve yapraklarından oluşan helozonik kıvrımlı kompozisyonlar 6.yy’da en yaygın kullanılan motiflerden biri haline gelmiştir. Bilhassa bu kompozisyon biçimi Kilise ve sinagog kompozisyonlarda görülmektedir. Aynı zamanda villaların, hamamların ve mezar odalarının dekore edilmiş zeminlerinde de yaygın olarak kullanılmıştır. Bu kompozisyon anlayışı Helenistik ve Roma döneminde ortaya çıkmıştır. Germenicia mozaiklerinin bu kompozisyon anlayışı Tunus, Türkiye, İsrail, Suriye, Filistin gibi ülkelerde görülmektedir.Örneğin, M.S. 6. Yüzyıl'da Hazor-Ashdod'dakiJudea Kilisesi'ndeki mozaiklerle (512 tarihli), Gazze MaiumasSinagog'undaki, Herodium'daki Doğu kilisesindeki mozaiklerle oldukça Benzerlikler göstermektedir. Gresa'daki St. George kilisesinin güney koridorundaki mozaik örneğinde olduğu gibi (Bknz; Hachlili, 122-130).
Germenicia Mozaikleriyle, Kuzey Afrika'da, İsrail'de, Ürdün'de ortaya çıkarılan mozaiklerin kompozisyon ve içeriklerineredeyse birbirinin aynısıdır. Farklılı yerel/gündelik kültüre ait yaşam biçimindedir.

\section{Sonuç}

Kahramanmaraş tarihte birçok medeniyete ev sahipliği yapması sebebiyle kültürel açıdan oldukça zengin bir kenttir. Hititler döneminde Markasi olarak bilinen kenti M.Ö. 58'deBüyük Roma İmparatorluğu ele geçirmiş ve Kommagene Krallığına bağlayarak şehre Germenicia adını vermiştir.

Germenicia mozaikleri M.S. 2. Yüzyıl ile 5. Yüzyıl arasında Romalılar tarafından zemin mozaiği olarak yapılmıştır.Germenicia mozaiklerinin yapımında renkli doğal taş parçalarının yanı sıra farklı tesseralarında kullanıldığı görülmüştür. Zeugma, Halepli Bahçe, Antakya gibi yakın çevre mozaiklerinde Antik Yunan ve Roma mitolojisi hakim iken, Germenicia Mozaiklerinde ise gündelik konular ele alınmıştır. Germenicia mozaiklerinin konu ve konuyu işleyiş biçimleri, kompozisyonlardaki kıvrımlı asma dalları ve içlerinde yer alan hayvan tasvirleri Lübnan, Suriye, İsrail, Filistin gibi ülkelerde ortaya çıkarılan mozaiklerle oldukça benzerlikler taşıdığı anlaşılmıştır.Kahramanmaraş Germenicia mozaiklerinin benzerlikleri bakımından Kuzey Afrika ülkeleri hattı üzerinde araştırılması gerekliliği ortaya çıkmıştır.

\section{Kaynakça}

Ekincioğlu, G., Başıbüyük, Z., Gölbaş, A., KayduAkbudak, İ, (2018).Geçmişten Günümüze Doğaltaş Mozaik Sanatı ve Geleceğe Aktarılması, International Journal of InterdisciplinaryAndIntercultural Art; Volume: 3, Issue: 4, June/July/ Summer: 81-91.

Eraslan, Ş, (2013). 'Germenicia Mozaiklerinde Av Sahneleri: Doğu Ve Batıdan Örneklerle İkonografik Bir Değerlen dirme', Uluslar Arası Türk Ve Dünya Kültüründe Kahramanmaraş Sempozyumu. 225-234.

Ersoy, A. (2010). Dağların Gazeli Maraş, (Haz. F, Özdem), İstanbul: Y.K.Y.

Fisher, P. (1971).Mosaic History and Technique, New York- Toronto: McGraw-HillBookCompany.

Genç, A.(1994). Bizans ve Romadaki Mozaik Sanatı, İzmir: Dokuz Eylül üniversitesi Güzel Sanatlar Fakültesi Magazin, VIII-IX. 87-93. 
Gökhan, İ. (2014). Roma Ve Bizans Dönemlerinde Germanicia (Maraş).Cappadociajournal Of Hystory And Social Sciences. Volume 2. 76-87.

Gür, S. 2007).Anadolu Uygarlıkları ve Antik Şehirler, İstanbul: Alfa Yayınları.

Hachlili; R. (2009); Ancient Mosaic Pavements, Leiden Boston: Hotei Publishing, Brill.

Kaplan, Z.; İpekoğlu, B.ve Böke, H.; Roma Dönemi Döşeme Mozaiklerinin Yapım Tekniği ve Malzeme Özellikleri 6. Uluslar arası tarihi Yapıların Güçlendirilmesi Sempozyumu, 2-4 Kasım 2017, Trabzon. 237-245.

Koç, A. (2009).Kaçak Kazı nedeniyle T.C. Kahramanmaraş III. Asliye Ceza Mahkemesi Hakimliğine verilen 2008/729 Dosya No'luGermenicia Mozaikleri Hakkında Yayımlanmamış Bilirkişi Raporu.

Küçük, C. ve Yar, M. (2012). Kahramanmaraş Mozaikleri Konservasyon Çalışmaları, V. 5. Journal Of Mosaic Reasearch. 88-95.

Sözen, M. ve Tanyeli U. (1996).Sanat Kuram ve Terimleri Sözlüğü, İstanbul: Remzi Kitabevi.

Şahin, M. (2011) http:// www.haberler.com (13. 03. 2019).

Üstüner, A. C. (2002). Mozaik Sanatı, İstanbul: Engin Yayınevi.

http://www. turktoyu.com (11.01.2019) 